Available online at http://journal.stkip-andi-matappa.ac.id/index.php/histogram/index

Histogram: Jurnal Pendidikan Matematika 4(2)., 2020, 479 - 499

\title{
PENGEMBANGAN PERANGKAT PEMBELAJARAN MATERI HIMPUNAN MODEL RESIK BERBASIS SCIENTIFIC DI SMP
}

\begin{tabular}{c} 
Putriyani S', Hafsyah ${ }^{2}$, Suparman $^{\mathbf{3}}$ \\
1,2,3 Universitas Muhammadiyah Enrekang \\
* Corresponding Author. Email: putriyani49@gmail.com \\
Received: 05 Agsustus 2020; Revised:15 September 2020; Accepted: 30 September 2020 \\
\hline
\end{tabular}

\section{ABSTRAK}

Penelitian ini bertujuan menghasilkan perangkat pembelajaran model RESIK berbasis scientific yang valid, praktis, dan efektif digunakan selama belajar di rumah dalam masa pandemic Covid-19. Perangkat pembelajaran yang dikembangkan antara lain: 1) Rencana Pelaksanaan Pembelajaran (RPP) yang disesuaikan selama masa belajar di rumah, 2) Buku Siswa, dan 3) Lembar Kerja. Penelitian dilaksanakan di SMPS Muhammadiyah Enrekang dengan subjek penelitian adalah peserta didik Kelas VII Tahun Ajaran 2019/2020. Model pengembangan perangkat yang digunakan mengacu pada four D Models (model 4-D) yang terdiri atas empat tahap, yaitu pendefinisian (define), perancangan (design), pengembangan (develop), dan penyebaran (disseminate). Proses penelitian dan penyebaran instrumen dilakukan via daring dengan memanfaatkan aplikasi Zoom, Whatsapp, dan Google Form. Pada tahap perancangan dihasilkan draft RPP 4 kali pertemuan, Buku Siswa, dan LK. Tahap pengembangan melalui tahap validasi ahli dan ujicoba lapangan diperoleh: 1) Hasil validasi ahli menunjukkan bahwa RRP, Buku Siswa, dan Lembar Kerja baik dan dapat digunakan dengan revisi kecil; 2) Hasil ujicoba lapangan menunjukkan RPP, Buku Siswa, dan Lembar Kerja tidak perlu direvisi. Sedangkan untuk respons siswa positif dan tes hasil belajar dilihat dari ketuntasan klasikal yang didapat cukup layak digunakan. Produk yang dihasilkan dari penelitian ini yaitu perangkat pembelajaran untuk materi Himpunan yang valid, praktis, dan efektif.

Kata Kunci: Pengembangan perangkat Model Resik.

\section{ABSTRACT}

This research aims to produce learning tools on the RESIK learning model and scientific approach that is valid, practical, and effective. The learning tool used for home studying during the Covid-19 pandemic. Learning tools developed include 1) lesson plans used for, 2) Student Books, and 3) Worksheets. The research was conducted at SMP Muhammadiyah Enrekang with the research subjects being Class VII students in the 2019/2020 Academic Year. The development of the learning tool refers to four D Models (4-D models) consisting of four stages, namely defining, designing, developing, and disseminating. The process of research and dissemination of instruments is done online by using the Zoom, Whatsapp, and Google Form. At the design stage, the draft RPP produced 4 meetings, Student Books, and Student Workbooks. The development stage through the expert validation stage and field trials is obtained: 1) The results of the expert validation showed that the lesson plan, Student Book, and Worksheet are good and can be used with minor revisions; 2) The results of the field trials showed that lesson plans, student books, and worksheets did not need to be revised. Whereas for positive student responses and learning outcomes tests seen from classical completeness obtained was quite feasible to use. The products from this research are valid, practical, and effective learning tools for set material.

Keywords: Learning tools on Resik Model

How to Cite: Syamsul, P., Hafsyah., \& Suparman. (2020). Pengembangan Perangkat Pembelajaran Materi Himpunan Model Resik Berbasis Scientific Di SMP. Histogram: Jurnal Pendidikan Matematika, 4(2), 479 - 499, doi: http://dx.doi.org/10.31100/histogram.v4i2.718

Permalink/DOI: http://dx.doi.org/10.31100/histogram.v4i2.718

\section{PENDAHULUAN}

Salah satu ilmu dasar yang mempunyai peranan penting dalam penguasaan sains dan teknologi adalah matematika, baik aspek terapan maupun penalarannya. Mata

Copyright $($ C 2020, THE AUTHOR (S). This article distributed under the CC-BY-SA-license. 


\section{Histogram: Jurnal Pendidikan Matematika, 4 (2), 2020 - 480 \\ Putriyani S1, Hafsyah², Suparman³}

pelajaran matematika perlu diberikan kepada semua siswa mulai dari sekolah dasar. Tujuan diberikannya matematika di sekolah karena siswa memerlukan matematika untuk memenuhi kebutuhan praktis dan memecahkan masalah dalam kehidupan sehari-hari, serta membantu memahami bidang studi lain agar siswa dapat berpikir logis, kritis, praktis, bersikap positif dan berjiwa kreatif.

Namun siswa masih menganggap matematika sebagai mata pelajaran yang cukup rumit, namun pemikiran tersebut tidak serta merta menjadi motivasi bagi siswa agar lebih giat mempelajari matematika. Perlu dipahami bahwa, siswa bukan satusatunya objek dalam proses pembelajaran. Guru juga merupakan objek yang tak kalah penting dalam memotivasi serta membimbing siswa dalam pembelajaran. Tujuan utama seorang guru pada setiap kegiatan pembelajaran adalah agar siswanya dapat memperoleh hasil sebaik mungkin sesuai tujuan pembelajaran yang telah direncanakan sebelumnya. Untuk mewujudkan tujuan tersebut maka guru perlu melakukan beberapa langkah, salah satunya yaitu memperhatikan penyebab kesulitan siswa dalam proses pembelajaran, baik yang bersumber dari diri siswa itu sendiri maupun yang bersumber dari luar diri siswa.

Salah satu penyebab kesulitan yang bersumber dari luar siswa adalah rendahnya kemampuan guru dalam menggunakan metode pembelajaran yang bervariasi. Dibutuhkan profesionalisme dan kreativitas guru dalam kegiatan pembelajaran, salah satunya yaitu mampu menyusun perangkat pembelajaran yang sesuai dengan Kurikulum 2013. Strategi pembelajaran yang sesuai dengan Kurikulum 2013 adalah pendekatan scientific.

Seorang guru dalam proses pembelajaran perlu mempersiapkan perangkat pembelajaran sebagai sarana untuk memudahkan siswa dalam memahami materi matematika yang disajikan, sekaligus memudahkan guru dalam menerapkan standar kompetensi lulusan yang ditetapkan. Pembelajaran akan bermakna apabila dalam proses pembelajaran guru mengaitkan materi yang dipelajari dengan lingkungan sekitar. Dengan semangat belajar seraya berlomba mengacungkan tangan untuk mengungkapkan pendapat masing-masing. Siswa yang awalnya sering diam pun ikut memberi pendapat mengenai solusi masalah yang diberikan oleh pendidik.

Model pembelajaran yang tepat digunakan yaitu model pembelajaran RESIK (Realistik Setting Kooperatif). Beberapa penelitian dengan beragam subyek melaporkan keunggulan model pembelajaran RESIK (Suryanata, et al, 2014, ,Dewi, et al, 2017, 


\section{Histogram: Jurnal Pendidikan Matematika, 4 (2), 2020 - 481 \\ Putriyani S1, Hafsyah², Suparman³}

Abdurahim, 2016, Ilah, 2017, dan Supraptinah, Budiyono, \& Subanti, 2015). Model pembelajaran RESIK menyajikan masalah kontekstual diawal pembelajaran kemudian masalah tersebut diselidiki oleh siswa dengan bantuan scaffolding oleh pendidik untuk mengetahui solusi dari masalah tersebut (Irawati, 2017). Cara seperti ini merupakan stimulus yang dapat meningkatkan minat belajar dan kreativitas siswa terutama dalam hal pemecahan masalah sehingga perkembangan non-kognitif selaras dengan perkembangan kognitif yang dimiliki siswa (Dewi, Wiarta, \& Suniasih, 2017; Syahri, 2017; N.W.A. Prastyani, 2019).

Sementara pendekatan pembelajaran yang sangat cocok disandingkan dengan model pembelajaran Resik adalah pendekatan scientific yang mengarahkan guru harus menyajikan pembelajaran yang dapat meningkatkan rasa keingintahuan, meningkatkan keterampilan mengamati, melakukan analisis dan berkomunikasi (Wibowo, 2017, Zagoto \& Dakhi, 2018). Oleh karena itu penelitian ini dilakukan untuk mengembangkan perangkat pembelajaran matematika. Produk hasil pengembangan perangkat dapat digunakan pada pembelajaran yang menerapkan model realistik setting kooperatif yang berbasis scientific. Sehingga pelaksanaan model pembelajaran didukung oleh tersedianya perangkat yang sesuai serta diharapkan dapat membantu guru untuk mencapai tujuan pembelajaran yang diharapkan.

Dari uraian latar belakang di atas, maka pertanyaan penelitian dirumuskan sebagai berikut: (1) bagaimana mengembangkan perangkat pembelajaran Materi Himpunan Model Resik berbasis scientific?; (2) Bagaimana hasil pengembangan perangkat pembelajaran Materi Himpunan Model Resik berbasis scientific?

Penelitian ini bertujuan menghasilkan perangkat pembelajaran yang digunakan oleh pendidik/ guru untuk mengatasi kesulitan belajar matematika pada materi Himpunan. Produk yang dihasilkan dari penelitian ini dimanfaatkan untuk mendukung keterlaksanaan model pembelajaran RESIK berbasis scientific sehingga tujuan pembelajaran yang diharapkan dari siswa dapat tercapai. Produk yang dihasilkan dapat dimanfaatkan oleh guru selama pembelajaran di rumah.

\section{METODE PENELITIAN}

Penelitian ini dilaksanakan di SMPS Muhammadiyah Enrekang dengan subjek penelitian yaitu siswa Kelas VII Tahun Ajaran 2019/2020. Prosedur pengembangan perangkat mengacu pada pengembangan four D Models (model 4-D) yang terdiri atas 


\section{Histogram: Jurnal Pendidikan Matematika, 4 (2), 2020 - 482}

Putriyani S', Hafsyah ${ }^{2}$, Suparman ${ }^{3}$

empat tahap, yaitu pendefinisian (define), perancangan (design), pengembangan (develop), dan penyebaran (disseminate), sebagaimana dikemukakan oleh Thiagarajan, Semmel \& Semmel (1974). Prosedur penelitian ini dapat dilihat pada Gambar 1 berikut:

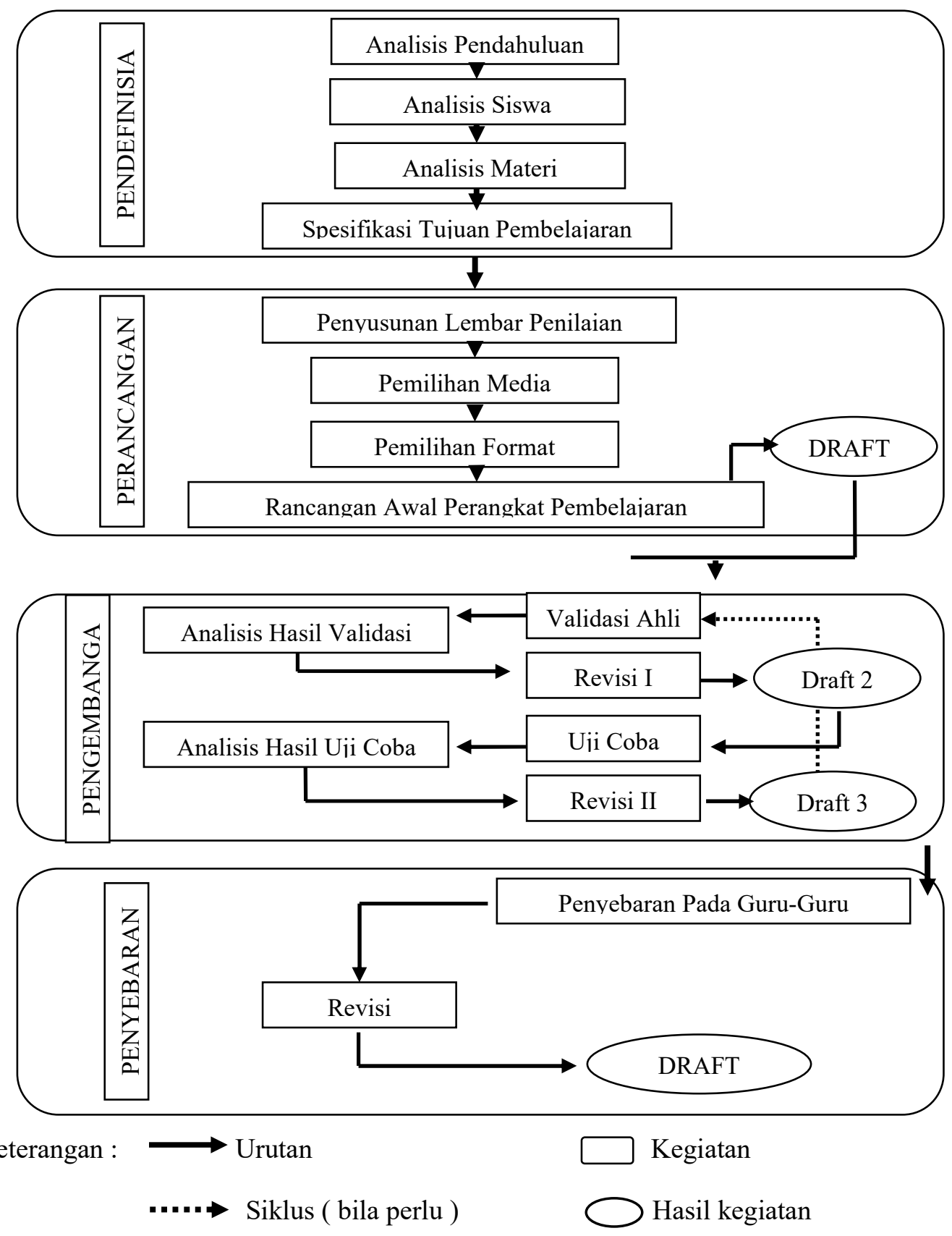

Gambar 1. Prosedur Penelitian

1. Tahap Pendefinisian (Define) 


\section{Histogram: Jurnal Pendidikan Matematika, 4 (2), 2020 - 483 \\ Putriyani S1, Hafsyah², Suparman³}

Tahap ini bertujuan untuk menetapkan dan mendefinisikan kebutuhankebutuhan pembelajaran dengan menganalisis tujuan dan batasan materi. Tahap ini dilakukan dengan melakukan wawancara via daring dengan beberapa siswa dan guru mata pelajaran Matematika. Hal-hal yang ditanyakan meliputi: pelaksanaan Kurikulum 2013, perangkat pembelajaran yang digunakan, dan karakteristik siswa. Hasil wawancara kemudian didefinisikan kedalam bentuk: analisis pendahuluan, analisis krateristik siswa, analisis materi, analisis tugas dan spesifikasi tujuan pembelajaran.

a. Analisis pendahuluan: Bagian ini menjelaskan hasil telaah kurikulum matematika 2013 yang berlaku dan perangkat-perangkat pembelajaran untuk pokok bahasan himpunan yang ada di sekolah, apakah sudah sesuai dengan pembelajaran matematika realistik.

b. Analisis karakteristik siswa: Bagian ini mendefinisikan karakteristik siswa yang akan menjadi acuan penyusunan rancangan dan pengembangan bahan pembelajaran. Karakteristik siswa yang didefinisikan meliputi: latar belakang pengetahuan, pengalaman-pengalaman sebelumnya, sikap terhadap materi pembelajaran, bahasa dan perkembangan kognitif siswa.

c. Analisis materi: Bagian ini mengidentifikasi topik-topik utama pada materi himpunan yang akan dipelajari siswa dan menyusunnya dalam skema topik.

d. Analisis tugas: Tahap mengidentifikasi tugas-tugas atau keterampilan-keterampilan utama yang harus dimiliki siswa setelah melakukan pembelajaran materi himpunan berdasarkan analisis materi.

e. Spesifikasi tujuan pembelajaran: Menjabarkan hasil analisis materi dan analisis tugas kedalam tujuan pembelajaran.

2. Tahap Perancangan (Design)

Tahap ini dimulai setelah ditetapkan tujuan pembelajaran. Kegiatan pada tahap ini adalah : (a) penyusunan lembar penilaian, (b) Pemilihan media, (c) pemilihan format, (d) perancangan awal perangkat pembelajaran. Perangkat pembelajaran yang dirancang digunakan selama 4 kali pertemuan untuk materi Himpunan. Rancangan awal perangkat pembelajaran berupa Rencana Pelaksanaan Pembelajaran (RPP), Buku Siswa, dan Lembar Kerja sebagai draft 1.

3. Tahap Pengembangan(Develop)

Tujuan dari tahap pengembangan ini adalah untuk menghasilkan draft 2 


\section{Histogram: Jurnal Pendidikan Matematika, 4 (2), 2020 - 484 \\ Putriyani S1, Hafsyah², Suparman³}

perangkat pembelajaran yang telah direvisi berdasarkan masukan para ahli dan data yang diperoleh dari ujicoba. Kegiatan pada tahap ini adalah validasi ahli dan ujicoba lapangan. Tahap validasi ahli dilakukan dengan menyiapkan lembar validasi perangkat dan berkonsultasi dengan para ahli. Validator pada penelitian ini adalah 2 orang dosen pendidikan matematika dan 1 orang guru matematika smp. Hasil revisi dari validator (revisi I) selanjutnya diujicobakan dan hasilnya dianalisis untuk selanjutnya direvisi (revisi II). Tahap ujicoba lapangan dilakukan dengan menyiapkan instrumen penelitian. Instrumen yang disiapkan yaitu: (a) lembar penilaian terhadap perangkat pembelajaran (lembar penilaian perangkat), (b) lembar observasi keterlaksanaan perangkat pembelajaran; (c) lembar observasi aktivitas siswa, (d) lembar observasi pengelolaan pembelajaran, (e ) angket respon siswa, dan (f) tes hasil belajar.

4. Tahap Penyebaran (Desiminate)

Pada tahap ini perangkat pembelajaran yang telah diujicobakan dan direvisi kemudian disebarkan, tetapi penyebaran dalam penelitian ini hanya sebatas sosialisasi kepada guru- guru di tempat penelitian guna memperoleh saran-saran atau masukan yang dijadikan bahan pertimbangan dalam merivisi perangkat pembelajaran yang telah dikembangkan. Hasil revisi pada tahap ini menghasilkan draft final perangkat pembelajaran materi Himpunan.

\section{HASIL DAN PEMBAHASAN}

\section{A. Hasil Tahap Pendefinisian (Define)}

Kegiatan yang dilakukan dalam tahap ini adalah analisis pendahuluan, analisis krakteristik siswa, analisis materi, analisis tugas, dan spesifikasi tujuan pembelajaran. Kegiatan ini ditetapkan terlebih dahulu sebagai landasan untuk melangkah ke tahap-tahap pengembangan selanjutnya. Hasil setiap kegiatan pada tahap pendefinisan diuraikan sebagai berikut:

1. Hasil Analisis Pendahuluan

Dari hasil analisis yang telah dilakukan di SMPS Muhammadiyah Enrekang tentang pelaksanaan dan hasil belajar, ternyata diperoleh bahwa hasil belajar matematika siswa masih rendah. Proses belajar di kelas VII SMP Muhammadiyah Enrekang kurang memberikan kesempatan kepada siswa untuk mengembangkan dan mengkonstruksi pengetahuannya sendiri. Siswa kurang bersemangat untuk mengikuti pembelajaran serta malas untuk bertanya apalagi mengemukakan pendapat atau jalan pikiran sendiri tentang 


\section{Histogram: Jurnal Pendidikan Matematika, 4 (2), 2020 - 485 \\ Putriyani S1, Hafsyah², Suparman3}

materi pelajaran yang sedang dipelajari. Proses belajar lebih banyak di dominasi oleh guru sementara siswa hanya mendengarkan dan mencatat apa yang disampaikan oleh guru bahkan terkadang siswa melakukan kegiatan lain yang tidak berhubungan dengan pembelajaran seperti bercerita dengan teman, saling menganggu satu sama lain atau bahkan keluar kelas.

2. Hasil Analisis Krakteristik Siswa.

Karakteristik siswa yang ditelaah dalam penelitian pengembangan ini adalah karakter siswa kelas VII SMPS Muhammadiyah Enrekang. Karakteristik ini meliputi latar belakang pengetahuan, bahasa yang digunakan, dan perkembangan kognitif siswa. Latar belakang pengetahuan siswa, siswa belum memperoleh topik Himpunan tetapi siswa sudah sering berhubungan dengan Himpunan dalam kehidupan sehari-hari, siswa kelas VII SMPS Muhammadiyah Enrekang juga telah mempelajari pengetahuan prasyarat yaitu bilangan. Bahasa yang digunakan siswa dalam proses pembelajaran sebagian besar adalah bahasa Indonesia. Mereka masih memerlukan benda-benda konkret dalam pembelajaran matematika. Oleh karena itu, sangat tepat bila pembelajaran matematika diawali dengan masalah kontekstual yang dekat dengan kehidupan sehari-hari siswa.

3. Hasil Analisis Materi/Topik

Materi pelajaran yang digunakan dalam penelitian ini adalah materi pokok Hiimpunan untuk SMP kelas VII dengan mengacu pada Kurikulum 2013.

Dengan memperhatikan prinsip dan karakteristik PMR, maka garis besar materi yang digunakan pada penelitian ini dapat dilihat pada diagram berikut:

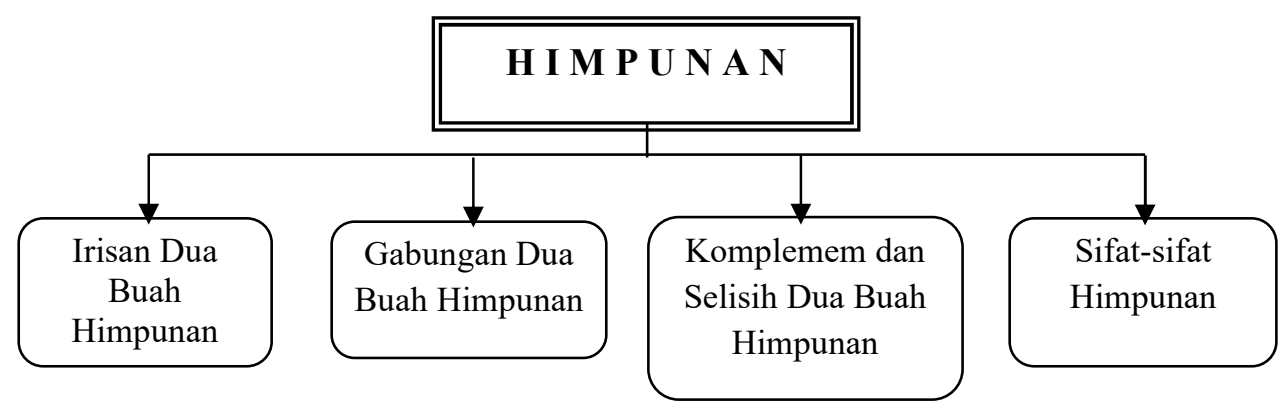

Gambar 2. Materi Pokok Himpunan Berdasarkan Kurikulum 2013

\section{Hasil Analisis Tugas}

Pada tahap ini juga diidetifikasi tugas yang dikuasai oleh siswa. Hasil analisis ini meliputi tugas umum dan khusus, yaitu sebagai barikut:

a. Tugas umum/Kompetensi Dasar (KD) 


\section{Histogram: Jurnal Pendidikan Matematika, 4 (2), 2020 - 486 \\ Putriyani S1, Hafsyah², Suparman3}

Memahami pengetahuan (faktual, konseptual, dan prosedural) berdasarkan rasa ingin tahunya tentang ilmu pengetahuan, teknologi, seni, budaya terkait fenomena dan kejadian tampak mata

b. Tugas Khusus

Tugas khusus untuk sub topik Irisan adalah:

1) Menjelaskan pengertian Irisan Dua Himpunan.

2) Menyelesaikan masalah yang berkaitan dengan Irisan Dua Himpunan

Tugas khusus untuk sub topik Gabungan adalah

1) Menjelaskan pengertian gabungan Dua Himpunan

2) Menyelesaikan masalah yang berkaitan dengan Gabungan Dua Himpunan

Tugas khusus untuk sub topik Komplemen dan Selisih adalah:

1) Menjelaskan pengertian Komplemen Suatu Himpunan

2) Menjelaskan Pengertian Selisih Suatu Himpunan

3) Menyelesaikan masalah yang berkaitan dengan Kompelemen dan Selisih Dua Himpunan

Tugas khusus untuk sub topik Sifat-sifat Himpunan adalah: Memahami sifat sifat Operasi himpunan

5. Hasil Spesifikasi Tujuan Pembelajaran

Hasil dari spesifikasi tujuan pembelajaran untuk topik Himpunan ini adalah sebagai berikut:

a. Menjelaskan pengertian Irisan dua himpunan dengan menggunakan kata - kata sendiri

b. Menyelesaikan masalah yang berkaitan dengan irisan dua himpunan

c. Menjelaskan pengertian Gabungan dua himpunan dengan menggunakan kata - kata sendiri.

d. Menyelesaikan masalah yang berkaitan dengan gabungan dua himpunan.

e. Menjelaskan pengertian kompelemen dua himpunan dengan menggunakan kata - kata sendiri.

f. Menjelaskan pengertian Selisih Dua Himpunan dengan menggunakan kata - kata sendiri.

g. Menyelesaikan masalah yang berkaitan dengan komplemen dan selisih dua himpunan.

h. Menjelaskan sifat Idempoten pada operasi himpunan.

i. Menjelaskan sifat Identitas pada operasi himpunan. 


\section{Histogram: Jurnal Pendidikan Matematika, 4 (2), 2020 - 487 \\ Putriyani S1, Hafsyah², Suparman3}

j. Menjelaskan sifat Komutatif pada operasi himpunan.

k. Menjelaskan sifat Asosiatif pada operasi himpunan.

1. Menjelaskan sifat Distributif pada operasi himpunan.

B. Hasil Tahap Perancangan (Design)

1. Pemilihan Media

Media pembelajaran yang diperlukan meliputi: Buku Siswa dan Lembar Kerja. Alat bantu atau alat peraga yang digunakan dalam proses pembelajaran antara lain: papan tulis, spidol, mistar/penggaris, penghapus, buku tulis, pulpen/pensil, LCD , dan laptop.

2. Pemilihan Format

Format Format Buku Siswa dan LKS dibuat semenarik mungkin dan dilengkapi dengan soal-soal sehingga siswa akan tertarik dan termotivasi untuk belajar.

3. Perancangan Awal.

Kegiatan utama dalam tahap akhir kegiatan perancangan adalah penyusunan perangkat pembelajaran yang meliputi Buku Siswa dan Lembar Kerja. Pada tahap ini dihasilkan rancangan awal Buku Siswa untuk 4 kali pertemuan, dan Lembar Kerja untuk setiap pertemuan. Hasil pada tahap perancangan ini disebut draft I. Buku Siswa mengangkat masalah-masalah kontekstual yang memfasilitasi siswa untuk membangun dan mengkonstruksi pengetahan mereka sendiri. Selain itu buku ini dilengkapi pertanyaan-pertanyaan yang bersifat arahan berdasar pada masalah kontekstual yang diselesaikan. Komponen-komponen buku siswa antara laian adalah: Kompetensi Inti, Kompetensi Dasar (KD), Indikator, Motivasi, Apersepsi, Uraian Materi, masalah kontekstual, dan soal latihan mandiri. Sedangkan pada Lembar Kerja memuat masalahmasalah kontekstual yang terkait dengan materi yang akan dipelajari dan diberikan tempat untuk menjawab masalah kontekstual tersebut. LKS untuk penelitian ini berisi persoalan matematika bergambar, persoalan cerita matematis, atau operasi matematis.

4. Penyusunan tes hasil belajar

Berdasarkan indikator pencapaian hasil kompetensi yang ingin dicapai yang tertuang dalam RPP, maka disusunlah tes hasil belajar. Tes hasil belajar yang digunakan tergolong kedalam tes beracuan patokan (PAP), karena tes ini dugunakan untuk mengukur sebarapa jauh pencapaian hasil belajar yang telah dirumuskan. Tes hasil belajar ini dirancang khusus untuk evaluasi produk saja, walaupun evaluasi dalam pembelajaran resik tidak hanya dilihat dari tes hasil belajar semata, tetapi juga dilihat dari proses bagaimana siswa sampai pada tahap pembentukan konsep. Tes hasil belajar ini tediri dari 


\section{Histogram: Jurnal Pendidikan Matematika, 4 (2), 2020 - 488 \\ Putriyani S1, Hafsyah², Suparman3}

4 nomor dan waktu yang disediakan 80 menit. Penyusunan tes ini antara lain meliputi: Perancangan kisi-kisi, butir soal, dan pedoman penskoran. Untuk butir tes, kunci jawaban dan pedoman penskoran dapat dilihat pada lampiran kisi-kisi.

\section{Hasil Tahap Pengembangan}

1. Penilaian para Ahli

Setelah semua perangkat pembelajaran disusun dalam bentuk draft I, selanjutnya dilakukan penilaian ahli (validator). Hasil validasi para ahli digunakan sebagai dasar untuk melakukan revisi dan penyempurnaan terhadap perangkat pembelajaran (draft 2).

Penilaian yang dilakukan oleh validator meliputi indikator: format, bahasa, dan isi perangkat pembelajaran. Validitas perangkat pembelajaran akan ditentukan dengan mencocokkan rerata total validitas seluruh butir penilaian dengan kriteria validitas berikut:

$$
\begin{array}{ll}
3,5 \leq M \leq 4 & \text { sangat valid (sv) } \\
2,5 \leq M<3,5 & \text { valid (v) } \\
1,5 \leq M<2,5 & \text { cukup valid (cv) } \\
M<1,5 & \text { tidak valid (tv) }
\end{array}
$$

Dalam melakukan revisi, penulis mengacu pada saran-saran serta petunjuk validator. Secara umum semua penilaian validator terhadap perangkat pembelajaran memberikan kesimpulan yang sama yaitu perangkat pembelajaran ini berada pada penilaian baik dan dapat digunakan dengan sedikit revisi.

Berdasarkan hasil validasi para ahli, beberapa revisi yang dilakukan terhadap RPP, Buku Siswa, Lembar Kerja, dan Tes Hasil Belajar berturut-turut dapat dilihat pada tabel-tabel berikut:

a. Rencana Pelaksanaan Pembelajaran (RPP)

Aspek-aspek yang diperhatikan dalam memvalidasi pelaksanaan pembelajaran adalah Format RPP, Tujuan, Materi Prasayarat, Materi Pelajaran, Penilaian, Kegiatan Pembelajaran, Bahasa dan tulisan, Alokasi Waktu dan Manfaat/Kegunaan RPP. Berikut hasil validasi RPP untuk setiap aspek pengamatan :

Tabel 1. Rangkuman Hasil Validasi RPP

ISSN: 2549-6700(print),ISSN2549-6719(online) 
Histogram: Jurnal Pendidikan Matematika, 4 (2), 2020 - 489

Putriyani S', Hafsyah ${ }^{2}$, Suparman 3

\begin{tabular}{clcccc}
\hline \multirow{2}{*}{ No } & \multirow{2}{*}{ Uraian } & \multicolumn{3}{c}{ Validator / } & \multirow{2}{*}{ Nilai Validasi } \\
\cline { 3 - 5 } & & I & II & $\bar{x}$ & \\
\hline 1 & Format RPP & 3,42 & 3,14 & 3,36 & Valid \\
\hline 2 & Tujuan & 3,40 & 3,40 & 3,40 & Valid \\
\hline 3 & Materi Prasyarat & 3,50 & 3,50 & 3,5 & Sangat Valid \\
\hline 4 & Materi Pelajaran & 3,50 & 3,25 & 3,38 & Valid \\
\hline 5 & Penilaian & 3 & 3 & 3 & Valid \\
\hline 6 & Kegiatan & 3,56 & 3,78 & 3,7 & Sangat Valid \\
& Pembelajaran & & & & \\
\hline 7 & Bahasa dan Tulisan & 3,5 & 3,25 & 3,38 & Valid \\
\hline 8 & Alokasi Waktu & 4 & 4 & 4 & Sangat Valid \\
\hline 9 & Manfaat / & 3,5 & 3 & 3,25 & Valid \\
& Kegunaan & & & & \\
\hline & Rata-rata & 3,52 & 3,64 & 3,43 & Valid \\
\hline
\end{tabular}

(Sumber: Data Primer, Tahun: 2020)

Meskipun secara keseluruhan aspek maupun masing-masing aspek sudah memenuhi kriteria kevalidan, namun ada beberapa hal yang perlu diperhatikan untuk kesempurnaan RPP.

Tabel 2. Hasil Revisi RPP

\begin{tabular}{|c|c|c|}
\hline Yang Direvisi & Sebelum Revisi & Setelah Revisi \\
\hline $\begin{array}{l}\text { Format } \\
\text { penulisan RPP }\end{array}$ & $\begin{array}{l}\text { Dibuat sebanyak } 4 \text { RPP } \\
\text { (tiap pertemuan). }\end{array}$ & $\begin{array}{l}\text { Satu RPP, yang diuraikan } \\
\text { hanya } \\
\text { pembelajaran, } \\
\text { langkah-langkah } \\
\begin{array}{l}\text { pembelajaran } \\
\text { penilaian }\end{array}\end{array}$ \\
\hline $\begin{array}{l}\text { an alat } \\
\text { an }\end{array}$ & $\begin{array}{lr}\text { Penilaian } & \text { tidak } \\
\text { dimunculkan aspek } \\
\text { sikap spiritual dan } \\
\text { sikap social (sesuai } \\
\text { kurikulum 2013) } \\
\end{array}$ & $\begin{array}{l}\text { Dalam Penilaian sudah } \\
\text { ada sikap spiritual, sikap } \\
\text { sosial dan pengetahuan. }\end{array}$ \\
\hline $\begin{array}{l}\text { Tujuan } \\
\text { Pembelajaran }\end{array}$ & $\begin{array}{l}\text { Tujuan pembelajaran } \\
\text { tidak terinci peraspek } \\
\text { (sesuai kurikulum } \\
\text { 2013) }\end{array}$ & $\begin{array}{l}\text { Tujuan } \\
\text { dirinci a aspek sikap } \\
\text { spiritual, sikap sosial , } \\
\text { aspek pengetahuan } \\
\text { (proses dan produk ) } \\
\text { aspek keterampilan }\end{array}$ \\
\hline $\begin{array}{l}\text { Materi } \\
\text { Pembelajaran }\end{array}$ & $\begin{array}{l}\text { Materi hanya berisi } \\
\text { judul /materi inti dan } \\
\text { konsep dasar }\end{array}$ & $\begin{array}{l}\text { Materi diuraikan : Fakta, } \\
\text { konsep, prinsip dan } \\
\text { procedural }\end{array}$ \\
\hline $\begin{array}{l}\text { Model, } \\
\text { Pendekatan, } \\
\text { dan Metode }\end{array}$ & $\begin{array}{l}\text { Pendekatan } \\
\text { Pendekatan Ilmiah } \\
\text { Model : Resik }\end{array}$ & $\begin{array}{l}\text { Model : Problem Based } \\
\text { Learning } \quad \text { (Realistik } \\
\text { Setting Kooperatif) }\end{array}$ \\
\hline Pembelajaran & Pembelajaran & Pendekatan : Pendekatan \\
\hline
\end{tabular}




\section{Histogram: Jurnal Pendidikan Matematika, 4 (2), 2020 - 490}

Putriyani S', Hafsyah ${ }^{2}$, Suparman 3

\begin{tabular}{lll}
\hline Yang Direvisi & \multicolumn{1}{c}{ Sebelum Revisi } & \multicolumn{1}{c}{ Setelah Revisi } \\
\hline & Matematika Reealistik & Ilmiah \\
& Setting Kooperaatif) & Metode Pembelajaran : \\
& Metode Pembelajaran : & diskusi, pemberian tugas, \\
ekspositori, Tanya & penemuan terbimbing \\
jawab, pemberian tugas & \\
\hline
\end{tabular}

(Sumber: Data Primer, Tahun: 2020)

b. Buku Siswa

Aspek - aspek yang diperhatikan dalam memvalidasi buku siswa secara rinci dapat dilihat pada Tabel 3. Berikut adalah rangkuman hasil validasi buku teks pelajaran untuk setiap aspek penialaian

Tabel 3. Rangkuman Analisis Hasil Validasi Buku Siswa

\begin{tabular}{|c|c|c|c|c|c|}
\hline \multirow[t]{2}{*}{ No } & \multirow[t]{2}{*}{ Uraian } & \multicolumn{3}{|c|}{$\begin{array}{c}\text { Validator / } \\
\text { Nilai Validasi }\end{array}$} & \multirow[t]{2}{*}{ Ket. } \\
\hline & & I & II & $\bar{x}$ & \\
\hline 1 & Format Buku Siswa & 3,43 & 3,71 & 3,57 & Sangat Valid \\
\hline 2 & Isi Buku Siswa & 3,56 & 3,67 & 3,67 & Sangat Valid \\
\hline 3 & Bahasa dan Tulisan & 3,60 & 3,75 & 3,75 & Sangat Valid \\
\hline 4 & $\begin{array}{l}\text { Ilustrasi, Tata Letak } \\
\text { tabel dan Diagram } \\
\text { /Gambar }\end{array}$ & 3,75 & 3,75 & 3,75 & Sangat Valid \\
\hline 5 & $\begin{array}{l}\text { Manfaat / Kegunaan } \\
\text { Buku Siswa }\end{array}$ & 4,0 & 4,0 & 4,0 & Sangat Valid \\
\hline & Rata-rata & 3,59 & 3,67 & 3,67 & Sangat Valid \\
\hline
\end{tabular}

(Sumber: Data Primer, Tahun: 2020)

Meskipun secara keseluruhan aspek maupun masing-masing aspek sudah memenuhi kriteria kevalidan, namun ada beberapa hal yang perlu diperhatikan untuk kesempurnaan buku siswa.

Tabel 4. Hasil Revisi Buku Siswa

\begin{tabular}{lll}
\hline \multicolumn{1}{c}{$\begin{array}{c}\text { Hal yang } \\
\text { Direvisi }\end{array}$} & \multicolumn{1}{c}{ Sebelum Revisi } & \multicolumn{1}{c}{ Setelah Revisi } \\
\hline $\begin{array}{l}\text { Validator 2 } \\
\text { Fakta/informasi } \\
\text { sebagai } \\
\text { pengantar materi }\end{array}$ & $\begin{array}{l}\text { Fakta/informasi } \\
\text { ataupun gambar yang } \\
\text { diberikan kurang } \\
\text { sesuai dengan materi } \\
\text { yang dibahas. }\end{array}$ & $\begin{array}{l}\text { Fakta/informasi yang } \\
\text { diberikan baik berupa } \\
\text { gambar maupun } \\
\text { narasi/kalimat sudah } \\
\text { sesuai dengan materi. }\end{array}$ \\
\hline
\end{tabular}

(Sumber: Data Primer, Tahun: 2020) 
Histogram: Jurnal Pendidikan Matematika, 4 (2), 2020 - 491

Putriyani S', Hafsyah'², Suparman³

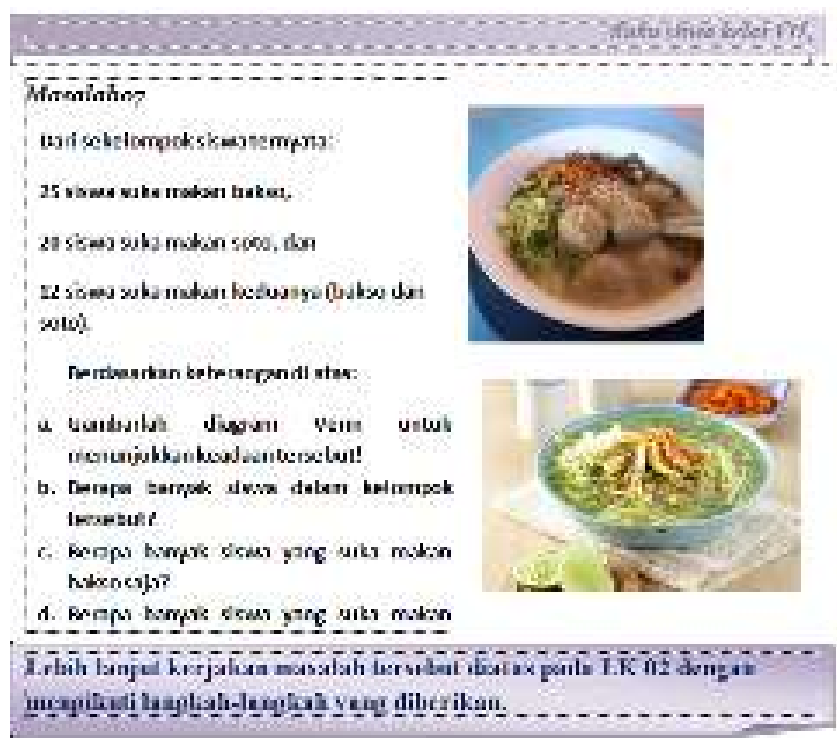

Gambar 3. Buku Siswa Sebelum Revisi

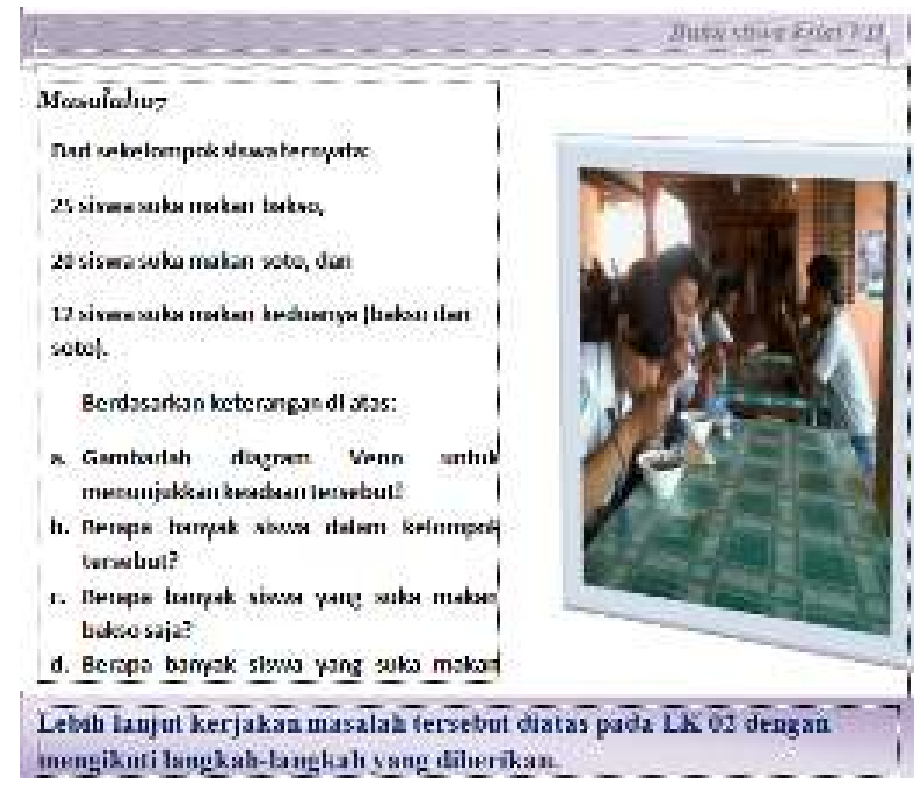

Gambar 4. Buku Siswa Setelah Revisi

c. Lembar Kerja

Aspek-aspek yang diperhatikan dalam memvalidasi lembar kerja adalah format, isi, bahasa dan tulisan, ilustrasi, tata letak tabel dan diagram / gambar, dan manfaat / kegunaan. Berikut adalah rangkuman hasil validasi RPP untuk setiap aspek pengamatan : 


\section{Histogram: Jurnal Pendidikan Matematika, 4 (2), 2020 - 492}

Putriyani S', Hafsyah ${ }^{2}$, Suparman 3

Tabel 5. Rangkuman Hasil Validasi Lembar Kerja

\begin{tabular}{clcccc}
\hline \multirow{2}{*}{ No } & \multirow{2}{*}{ Uraian } & \multicolumn{3}{c}{ Validator } \\
Nilai Validasi & \multirow{2}{*}{ Ket. } \\
\cline { 2 - 5 } & I & II & $\bar{x}$ & \\
\hline 1 & Format LK & 3,29 & 3,14 & 3,22 & Valid \\
\hline 2 & Isi LK & 3,33 & 3,5 & 3,42 & Valid \\
\hline 3 & Bahasa dan Tulisan & 3,4 & 3,4 & 3,4 & Valid \\
\hline \multirow{2}{*}{4} & $\begin{array}{l}\text { Ilustrasi, Tata Letak } \\
\text { tabel dan Diagram } \\
\text { /Gambar }\end{array}$ & 3,33 & 3,66 & 3,5 & Sangat Valid \\
\hline 5 & $\begin{array}{l}\text { Manfaat / Kegunaan } \\
\text { LK }\end{array}$ & 4,0 & 3,0 & 3,5 & Sangat Valid \\
\hline$\quad$ Rata-rata & 3,47 & 3,34 & 3,41 & Valid \\
\hline
\end{tabular}

(Sumber: Data Primer, Tahun: 2020)

Meskipun secara keseluruhan aspek maupun masing-masing aspek sudah memenuhi kriteria kevalidan, namun ada beberapa hal yang perlu diperhatikan untuk kesempurnaan Lembar Kerja.

Tabel 6. Hasil Revisi Lembar Kerja

\begin{tabular}{llrl}
\hline \multicolumn{1}{c}{ Hal yang Direvisi } & \multicolumn{2}{c}{ Sebelum Revisi } & \multicolumn{1}{c}{ Setelah Revisi } \\
\hline $\begin{array}{l}\text { Validator 1 } \\
\text { Tonjolkan tahapan } \\
\text { scientific }\end{array}$ & $\begin{array}{l}\text { Aktivitas } \\
\text { kurang } \\
\text { scientific }\end{array}$ & $\begin{array}{r}\text { kegiatan } \\
\text { tampak }\end{array}$ & $\begin{array}{l}\text { Aktivitas scientific sudah } \\
\text { kelihatan. }\end{array}$ \\
$\begin{array}{l}\text { Validator 2 } \\
\begin{array}{l}\text { Satukan buku teks } \\
\text { pelajaran dengan LK, } \\
\text { jangan dipisahkan. }\end{array}\end{array} \begin{array}{l}\text { Buku teks pelajaran } \\
\text { dibuat terpisah dengan } \\
\text { lembar kerja (LK). }\end{array}$ & $\begin{array}{l}\text { Lembar kerja berada di } \\
\text { dalam buku teks pelajaran }\end{array}$ \\
\hline
\end{tabular}

(Sumber: Data Primer, Tahun: 2020)
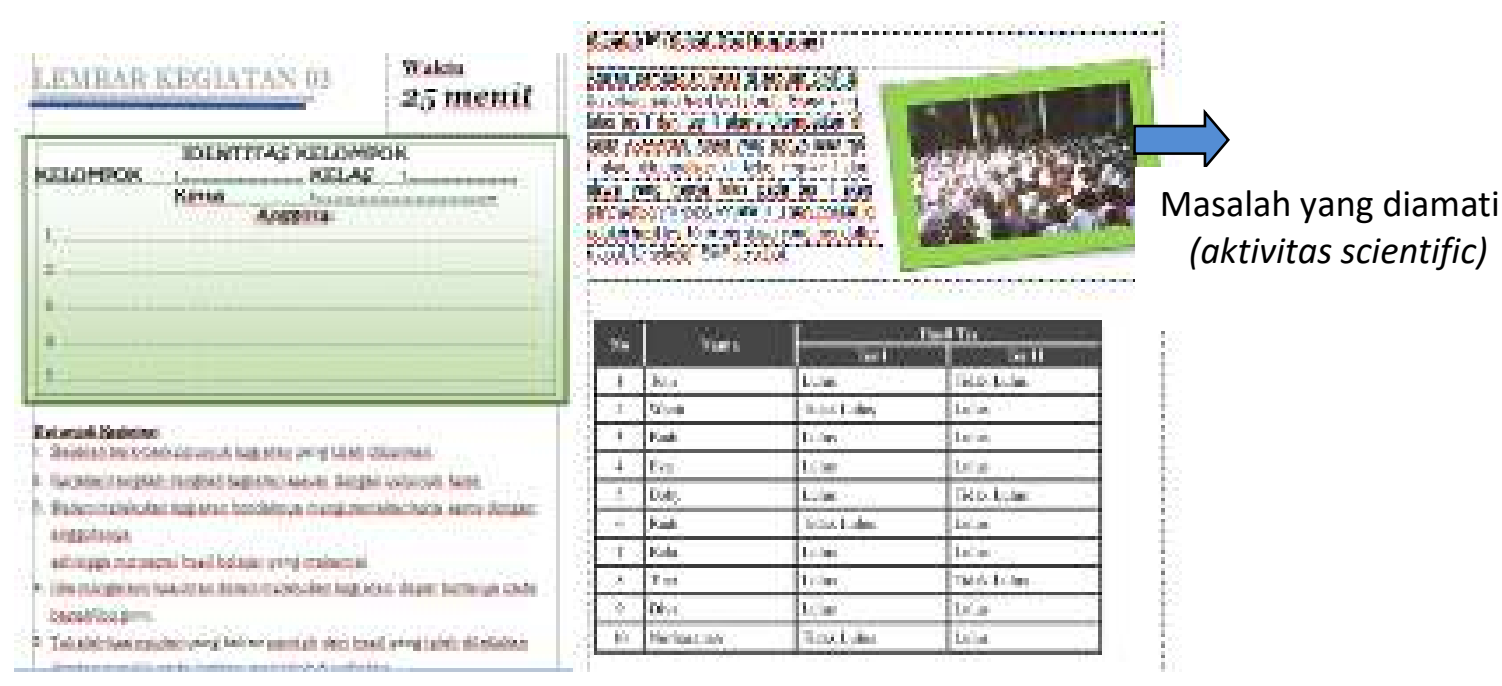
Histogram: Jurnal Pendidikan Matematika, 4 (2), 2020 - 493

Putriyani S', Hafsyah ${ }^{2}$, Suparman ${ }^{3}$

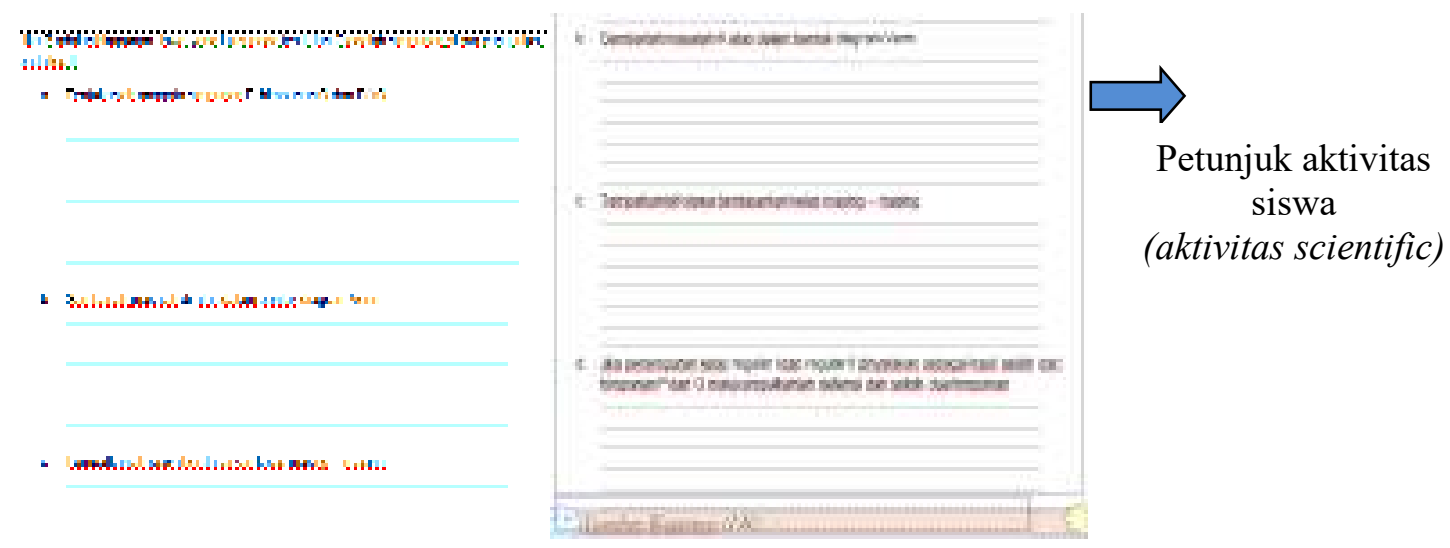

Gambar 5. Lembar Kerja Setelah Revisi Validator 1

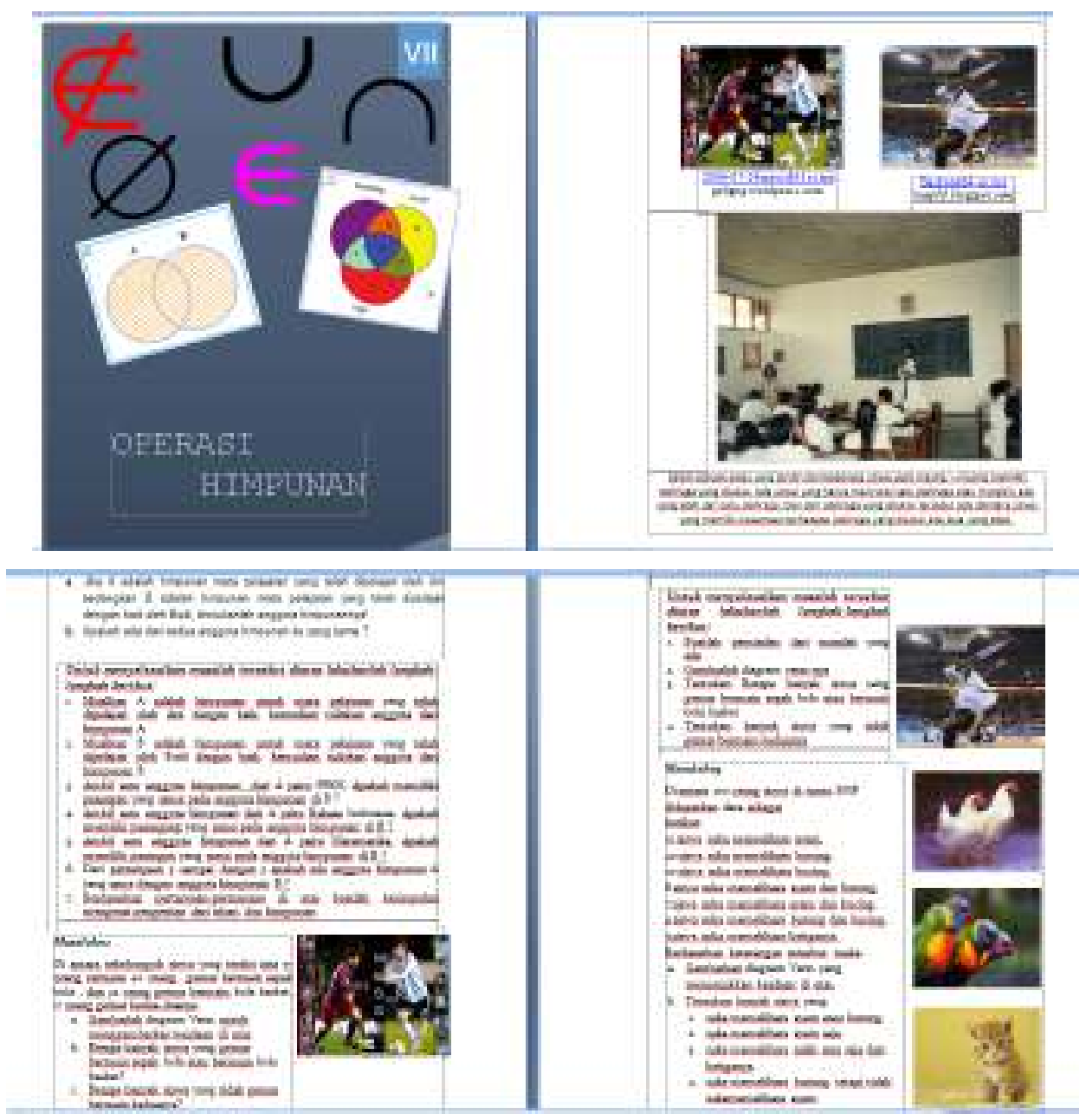

Gambar 6. Lembar Kerja Setelah Revisi Validator 2 


\section{Histogram: Jurnal Pendidikan Matematika, 4 (2), 2020 - 494 \\ Putriyani S', Hafsyah'2, Suparman³}

d. Tes hasil belajar

Tes hasil belajar disusun dengan mengacu pada kompetensi dasar dan indikator pembelajaran. Instrumen validasi untuk Tes hasil belajar memuat beberapa aspek yaitu aspek petunjuk dan aspek bahasa soal. Berdasarkan hasil penilaian 2 orang ahli menunjukkan bahwa dari segi validasi isi, Tes Hasil Belajar (THB) tergolong dalam kategori "Valid" dan dari segi bahsa soal, Tes Hasil Belajar (THB) tergolong dalam kategori "Dapat dipahami (DP)". Berdasarkan penilain validator terhadap instrumen Tes Hasil Belajar dapat disimpulkan bahwa instrument Tes Hasil Belajar (THB) tergolong dalam kategori "RK (dapat digunakan dengan revisi kecil)". Maka setelah dilakukan revisi kecil tes hasil belajar sudah bisa digunakan dan data yang diperoleh dengan instrument tersebut dapat digunakan untuk menilai keefektifan perangkat.

2. Ujicoba Lapangan

Perangkat pembelajaran hasil revisi berdasarkan saran dari para ahli (validator) selanjutnya diujicobakan pada siswa kelas VII SMPS Muhammadiyah Enrekang sebanyak 34 siswa yang terdiri atas 14 siswa laki-laki dan 20 siswa perempuan. Uji coba dilaksanakan selama 5 hari.

\section{Hasil Uji Coba Perangkat Pembelajaran}

Analisis efektivitas pembelajaran diukur menggunakan tiga indikator, yaitu: (a) kemampuan guru mengelola pembelajaran, (b) aktivitas siswa dan (c) respon dan minat siswa, maka berikut ini ketiga data hasil ujicoba perangkat pembelajaran beserta hasil analisisnya masing-masing.

a. Hasil Penilaian Kemampuan Guru Mengelola Pembelajaran.

Tingkat kemampuan guru dihitung dengan cara menjumlah nilai tiap aspek kemudian membaginya dengan banyak aspek yang dinilai. Untuk pengkategorian kemampuan guru tersebut digunakan kategori pada Tabel 7 berikut ini:

Tabel 7. Kriteria Tingkat Kemampuan Guru dalam Mengelola Kegiatan

\begin{tabular}{ccc}
\multicolumn{2}{c}{ Pembelajaran } \\
\hline No & $\begin{array}{c}\text { Nilai Rata-rata Tingkat } \\
\text { Kemampuan Guru }\end{array}$ & $\begin{array}{c}\text { Nilai Kualitas Kemampuan } \\
\text { Guru }\end{array}$ \\
\hline 1 & $1,00 \leq \mathrm{TKG}<1,50$ & tidak baik \\
2 & $1,50 \leq \mathrm{TKG}<2,50$ & kurang baik \\
3 & $2,50 \leq \mathrm{TKG}<3,50$ & cukup baik \\
4 & $3,50 \leq \mathrm{TKG}<4,50$ & baik \\
5 & $4,50 \leq \mathrm{TKG}<5,00$ & sangat baik \\
\hline
\end{tabular}

(Sumber: Rustiani et.al, Tahun: 2018) 


\section{Histogram: Jurnal Pendidikan Matematika, 4 (2), 2020 - 495 \\ Putriyani S1, Hafsyah², Suparman³}

Hasil penilaian oleh satu orang pengamat terhadap kemampuan guru dalam mengelola pembelajaran selama empat kali pertemuan via daring melalui Zoom diperoleh skor untuk empat pertemuan, yakni pada pertemuan pertama diperoleh skor rata-rata 3,96 (baik), pertemuan kedua dengan skor rata-rata 4,00 (baik), pada pertemuan ketiga diperoleh skor rata-rata 4,19 (baik), dan pada pertemuan keempat diperoleh skor rata-rata hasil pengamatan adalah 4,30 (baik). Pada pertemuan pertama, kemampuan guru dalam mengelola pembelajaran pada umumnya bernilai baik. Namun masih ada yang memperoleh nilai cukup baik yakni pada aspek :

1) Kemampuan guru memberi dorongan kepada Siswa untuk mengajukan pertanyaan terkait hal-hal yang diamati atau dicermati.

2) Kemampuan membimbing siswa untuk merangkum isi pembelajaran dan langkah langkah yang tepat dalam menyelesaikan masalah.

3) Kemampuan guru untuk memberikan bantuan terbatas kapada setiap kelompok.

Siswa masih ragu atau bahkan takut untuk bertanya, hal ini dimungkingkan karena guru belum optimal dalam memberi dorongan kepada siswa untuk betanya. Demikian pula dalam kegiatan merangkum isi pembelajaran, beberapa siswa masih belum mampu melakukannya dan kurang mampu untuk menentukan langkah-langkah yang tepat untuk menyelesaikan masalah dengan baik. Hal ini mungkin disebabkan karena guru belum memberikan bimbingan secara maksimal. Terbatasnya interaksi antara guru dan siswa dalam pembelajaran online membuat guru tidak dapat memberikan bimbingan secara maksimal. Guru tidak dapat berkeliling memberikan bantuan secara langsung kepada siswa selain siswa yang berani mengajukan pertanyaan.

Sedangkan pada pertemuan ketiga dan keempat kemampuan guru sudah mencapai kategori efektif pada semua aspek, dimana semua kemampuan guru sudah pada kategori baik bahkan sangat baik. Selanjut jika ditinjau dari kemampuan guru, perangkat yang digunakan pada seluruh pertemuan tidak perlu direvisi.

b. Hasil Pengamatan Aktivitas Siswa Selama Mengikuti Proses Pembelajaran

Hasil pengamatan aktivitas siswa selama mengikuti proses pembelajaran yang diberikan oleh satu orang pengamat selama empat kali pertemuan terhadap enam siswa yang dipilih sebagai sampel pengamatan.

Aktivitas siswa selama mengikuti proses pembelajaran untuk setiap pertemuan dapat dipaparkan sebagai berikut: (1) Mendengarkan/memperhatikan penjelasan guru dengan aktif diperoleh skor rata-rata 17,3, (2) Membaca/memahami soal/masalah 


\section{Histogram: Jurnal Pendidikan Matematika, 4 (2), 2020 - 496 \\ Putriyani S1, Hafsyah², Suparman³}

kontekstul diperoleh skor rata-rata 8,7, (3) Menjawab pertanyaan guru atau bertanya kepada guru diperoleh skor rata-rata 8,1, (4) Mendeskrepsikan dan menyelesaikan soal/masalah (diskusi kelompok) diperoleh 14,7, (5) Membandingkan jawaban dan berdiskusi dalam kelompok belajar diperoleh skor rata-rata 12,20, (6) Mempresentasikan atau menyampaikan jawaban diperoleh skor rata-rata 4,10, (7) Memperhatikan teman mempresentasikan jawaban dengan aktif diperoleh skor rata-rata 16,30, (8) Menanggapi jawaban teman atau menyampaikan pendapat/ide/gagasan kepada guru diperoleh skor rata-rata 7,9, dan (9) Menarik kesimpulan suatu prosedur atau konsep dengan kalimat atau cara sendiri diperoleh skor rata-rata 10,00.

c. Hasil Angket Respon Siswa terhadap Perangkat dan Pelaksanaan Pembelajaran

Dari hasil angket yang diberikan kepada 34 siswa setelah selesainya proses pembelajaran, diperoleh respon siswa terhadap komponen perangkat dan pelaksanaan pembelajaran. Respon siswa dengan kategori senang atau tidak senang pada komponen materi pelajaran, buku siswa dan cara guru mengajar, seluruh siswa (100\%) senang belajar dengan pembelajaran yang mengacu pada pendekatan PMR, namun pada komponen LKS terdapat 29 siswa atau $85,30 \%$ yang senang dengan pembelajaran yang mengacu pada pendekatan PMR, dan untuk komponen suasana belajar di kelas terdapat 28 siswa atau $82,40 \%$ yang senang dengan pembelajaran yang mengacu pada pendekatan PMR. Demikian pula terhadap perangkat pembelajaran (materi ajar,buku siswa, LKS), Semua siswa (30 orang) menyatakan bahwa pembelajaran yang mengacu pada pendekatan PMR ini baru bagi mereka, termasuk cara guru mengajar. Untuk kategori berminat atau tidak beminat, semua siswa berminat untuk mengikuti kegiatan belajar dengan pembelajaran yang mengacu pada pendekatan PMR. Semua siswa juga dapat memahami bahasa yang digunakan dalam buku siswa dan LKS. Demikian pula untuk penampilan buku siswa dan LKS, semua siswa menyatakan tertarik.

Dari uraian tentang respon siswa di atas dapat disimpulkan bahwa respon siswa terhadap pembelajaran yang mengacu pada PMR adalah positif, yakni rerata respon siswa terhadap setiap aspek di atas $75 \%$. Dengan demikian perangkat pembelajaran yang dikembangkan tidak perlu direvisi, dan model Resik perlu dijadikan suatu strategi mengajar dalam pembelajaran matematika secara daring.

d. Analisis Data untuk Merevisi Perangkat Tes Hasil Belajar Siswa

Hasil analisis deskriptif skor tes hasil belajar siswa setelah menggunakan perangkat pembelajaran model Resik dapat di lihat pada Tabel 8 berikut: 


\section{Histogram: Jurnal Pendidikan Matematika, 4 (2), 2020 - 497}

Putriyani S', Hafsyah ${ }^{2}$, Suparman 3

Tabel 8. Statistik Skor Hasil Belajar Matematika Siswa Pokok Bahasan Himpunan Kelas VII SMPS Muhammadiyah Enrekang

\begin{tabular}{cc} 
Variabel & Nilai Statistik \\
\hline Subjek Penelitian & 34 \\
Skor Ideal & 100 \\
Rata-rata & 80,53 \\
Standar Deviasi & 14,32 \\
Rentang Skor & 45 \\
Skor Maksimum & 100 \\
Skor Minimum & 55 \\
\hline
\end{tabular}

(Sumber: Data Primer, Tahun: 2020)

Dari Tabel 8 di atas menunjukkan bahwa skor rata-rata hasil belajar siswa adalah 80,53 dengan standar deviasi 14,32 dari skor ideal 100. Skor minimum yang diperoleh siswa adalah 55 dan skor masksimum yang diperoleh siswa adalah 100 dengan rentang skor 45. Jika skor aspek hasil belajar dikelompokkan dalam lima kategori, maka diperoleh hasil distribusi frekuensi sebagai berikut:

Tabel 9. Distribusi Frekuensi dan Persentase Skor Hasil Belajar Matematika Siswa Kelas VII SMPS Muhammadiyah Enrekang

\begin{tabular}{cccc}
\hline Skor & Kategori & Frekuensi & Persentase \\
\hline $0-34$ & Sangat Rendah & - & $0 \%$ \\
\hline $35-54$ & Rendah & - & $0 \%$ \\
\hline $55-64$ & Sedang & 8 & $23,53 \%$ \\
\hline $65-84$ & Tinggi & 12 & $35,29 \%$ \\
\hline $85-100$ & Sangat Tinggi & 14 & $41,18 \%$ \\
\hline & Jumlah & 34 & $100 \%$ \\
\hline
\end{tabular}

(Sumber: Data Primer, Tahun: 2020)

Tabel 9 di atas menunjukkan bahwa dari 34 siswa yang mengikuti tes hasil belajar tidak terdapat siswa $(0 \%)$ yang berada pada kategori sangat rendah dan rendah, 8 orang siswa $(23,53 \%)$ berada pada kategori sedang, 12 orang siswa $(35,29 \%)$ berada pada kategori tinggi dan 14 siswa $(41,18 \%)$ berada pada kategori sangat tinggi.

Skor rata-rata hasil belajar matematika siswa adalah 80,53 dari skor ideal 100 berada pada interval $65-84$. Dengan demikian, dapat disimpulkan bahwa hasil belajar matematika siswa berada pada kategori tinggi. 


\section{Histogram: Jurnal Pendidikan Matematika, 4 (2), 2020 - 498 \\ Putriyani S1, Hafsyah², Suparman³}

Dari keempat kriteria keefektifan, pada uji coba 4 aspek yang dipenuhi yaitu: kemampuan guru mengelola pembelajaran, aktivitas siswa, respon siswa, dan penguasaan tes hasil belajar. Berdasarkan kriteria keefektifan disimpulkan bahwa pada ujicoba, perangkat pembelajaran adalah efektif karena telah memenuhi 4 indikator keefektifan termasuk indikator tes penguasaan hasil belajar.

\section{Hasil Tahap Penyebaran}

Draft 3 yang diperoleh pada tahap pengembangan, selanjutnya disebarkan atau disosialisasikan secara terbatas pada guru-guru matematika SMPS Muhammadiyah Enrekang. Sosialisasi dilakukan secara daring dengan mengirimkan draft 3 pada grup Whatsapp. Dari tiga orang guru matematika SMPS Muhammadiyah Enrekang yang menjadi objek sosialisasi sependapat mengatakan bahwa perangkat pembelajaran yang dikembangkan sudah baik untuk diterapkan, namun mereka memberikan saran-saran untuk perangkat yang dikembangkan. Saran-saran dari guru antara lain:

1. Perangkat pembelajaran yang telah dikembangkan sebainya disosialisasikan lebih luas lagi kepada guru-guru di forum MGMP.

2. Pengembangan perangkat pembelajaran matematika model Resik berbasis scientific tidak hanya terbatas pada materi Himpunan, tetapi sebaiknya juga dilakukan untuk materi-materi yang lain karena membantu guru dalam mengelola pembelajaran via daring dengan aktivitas belajar tetap berpusat pada siswa (student center learning).

\section{KESIMPULAN DAN SARAN}

\section{A. Kesimpulan}

Perangkat pembelajaran materi Himpunan model Resik berbasis scientific dikembangkan dengan menggunakan 4D-model meliputi tahap pendefinisian (define), perancangan (design), tahap pengembangan (develop), dan tahap penyebaran (desiminate). Proses pengembangan perangkat menghasilkan produk yaitu RPP selama 4 kali pertemuan, Buku Siswa, dan Lembar Kerja setiap pertemuan. Perangkat pembelajaran yang dihasilkan digunakan selama pembelajaran di rumah pada masa pandemi Covid-19.

\section{B. Saran}

Produk yang dihasilkan terbatas dalam materi Himpunan. Sehingga untuk penelitian selanjutnya kami akan membuat produk serupa untuk materi/ pokok bahasan lain yang sesuai dengan model Resik. 


\section{Histogram: Jurnal Pendidikan Matematika, 4 (2), 2020 - 499}

Putriyani S', Hafsyah ${ }^{2}$, Suparman'3

\section{DAFTAR PUSTAKA}

Abdurahim,A. (2016). Keefektifan Model Pembelajaran Resik Ditinjau dari Sikap, Motivasi, dan Kemampuan Berpikir Kritis Matematis Siswa SMP. Jurnal Riset Pendidikan Matematika. 3(2), 137-149.

Dewi, N. L., Wiarta, I. W., \& Suniasih, N. W. (2017). Pengaruh Model Pembelajaran Realistik Setting Kooperatif (RESIK) Dipadukan Dengan Ice Breaking Terhadap Hasil Belajar Matematika. e-Journal PGSD Universitas Pendidikan Ganesha Mimbar PGSD,5 (2), 1-10.

Ilah, M. (2017). Pengaruh Model Pembelajaran Resik dan Kematangan Sosial terhadap Hasil Belajar IPS. Jurnal Pendidikan Dasar, 8(2), 25-35, doi.org/10.21009/JPD.082.03.

Irawati, T. N. (2017). Peningkatan Kemampuan Komunikasi Matematika Melalui Pembelajaran Matematika Realistik dengan Setting Kooperatif Tipe STAD (Student Teams Achievement Divisions). Jurnal Axioma: Jurnal Matematika dan Pembelajaran, 2 (1), 65-79.

N.W.A. Prastyani, I. I. (2019). Peningkatan Pemahaman Konsep Matematika Siswa Kelas X MIPA 2 SMA Negeri 1 Kediri Melalui Penerapan Model Pembelajaran Realistik dengan Setting Kooperatif Berbantuan LKS Terstruktur. Jurnal Pendidikan Matematika Undiksha, 10 (1), 65-74.

Rustiani, S., Hafsyah., \& Putriyani, S. (2018). Pengembangan Perangkat Pembelajaran Matematika Berbasis Masalah dengan Pendekatan Saintifik pada Pokok Bahasan Geometri untuk Peserta Didik SMA Kelas X. Jurnal Pendidikan Edumaspul, 2(2), $1-12$.

Supraptinah, U., Budiyono., \& Subanti, S. (2015). Eksperimentasi Model Pembelajaran Discovery Learning, Problem Based Learning, dan Think-Talk-Write dengan Pendekatan Saintifik terhadap Kemampuan Pemecahan Masalah Matematika ditinjau dari Kemandirian Belajar Siswa. Jurnal Pembelajaran Matematika, 3(10), 1138-1149.

Suryanata, K. A., Dantes, N., \& Margunayasa, I. G. (2014). Penerapan Pembelajaran Kooperatif Model RESIK (Realistik Setting Kooperatif) untuk Meningkatkan Hasil Belajar Matematika Siswa Kelas VI Semester I SD NO 6 PANJI Tahun Pelajaran 2014/2015. e-Journal Mimbar PGSD Universitas Pendidikan Ganesha Jurusan PGSD , 2(1), 1-10.

Wibowo, A. (2017). Pengaruh Pendekatan Pembelajaran Matematika Realistik dan Saintifik terhadap Prestasi Belajar, Kemampuan Penalaran Matematis, dan Minat Belajar. Jurnal Riset Pendidikan Matematika , 41, 1-10.

Zagoto, M. M., \& Dakhi, O. (2018). Pengembangan Perangkat Pembelajaran Matematika Peminatan Berbasis Pendekatan Saintifik untuk Siswa Kelas XI Sekolah Menengah Atas. Jurnal Review Pendidikan dan Pengajaran , 1 (1), 157169. 